tional advantages of operating from an airship is that under favourable conditions the shadow of the vessel appears on the photographs (Fig. 1), thus providing a control over the orientation and scale of the map.

As an example of what can be accomplished by airship survey, we reproduce the map (Fig. 2) of a part of south-eastern Novaya Zemlya showing the coastal region and the inland ice. The map is on the scale of $1 / 200,000$ with contours at $100 \mathrm{~m}$. intervals, and the errors in scale and height are stated not to exceed 10 per centprobably not 5 per cent. The latitude and longitude may be as much as $1^{\circ}$ out, and to correct this it would be necessary to determine by astronomical methods on the ground the true position of some point identifiable on the photographs, or to extend these to include some known point. L. H.

\title{
Obituary
}

\section{Sir DorabJi Tata}

$\mathrm{I}^{\mathrm{N}}$ the memorial to his wife which he settled shortly before his death on June 4, Sir Dorabji Tata described himself as "The Last of his House". That is painfully true; with his passing an end comes to a family which played a great part in the intellectual and industrial renaissance of India.

Dorab 'Tata's rôle in this was that of the executor rather than the creator. The pioneering was done by his father, Jamsetji Tata. Having founded the family fortune firmly by establishing a prosperous cotton-spinning business, he bent his adventurous talents to three great enterprises - the establishment of an Institute of Science to prepare Indians for the direction of modern large-scale industries ; the construction of iron and steel works as an essential link in the economic cycle; and the harnessing of the prolific rainfall of the Western Ghats to electric power stations to relieve the dependence of Bombay on far-distant coal-fields. But he died before any had reached the final stage ; on the contrary, the freedom with which he spent on the development work rather seriously ' locked up' the family resources.

At this stage Dorab Tata took control of the business. With the active sympathy of his brother, the late Sir Ratan Tata, he set himself the filial task of completing his father's work. After many discouragements, thanks to the co-operation of Lord Curzon and the Government of India, the Institute of Science was established at Bangalore. Thence a steady stream of well-trained Indians has passed into the service of Indian industry. Unfortunately, Bangalore, though admirably suited climatically, is so far from the industrial centres that its activities do not command the interest and support which they should receive; but the work goes on.

The history of the Iron and Steel Works at Jamshedpur reads like a romance. The dogged tenacity with which Dorab Tata and his expert advisers searched the Central Provinces for ore surprised even his closest friends ; for he was born to easy days. When their patience was rewarded by the discovery of a hill of iron ore of the finest quality at Gurumashini, the quest for capital was as baffling as that for "The Golden Girl ". British enterprise does not come well out of the test. Though the existence of the requisite materials was established beyond doubt, and the home market justified the establishment of large-scale manufacture, British capital was timid and exacting, and no progress was possible. Fortunately, on the crest of the swadesh $i$ wave India took this opportunity to itself and subscribed the money with an ease which surprised everyone; but equipment and operation were American and German when the British industrialist and financier missed their opportunity.

The same wave of constructive enthusiasm launched the hydro-electric works with Indian capital. Though the three associated companiesthe Tata Hydro-Electric, the Andhra Valley, and the Tata Power-are capable of delivering electrical energy in Bombay far beyond the capacity for absorption, the heavy capital cost, especially during construction, has not given industry the cheap power which it demanded.

Here Dorab Tata himself would have been glad to call a halt. He was a rather reluctant partner in the manifold activities into which his house launched, and which brought anxious days when the post-War reaction set in. But he rose to the occasion and placed his private fortune behind the Iron and Steel Company when the dark days came, and, backed by the indomitable courage of his cousin, the late Mr. R. D. Tata, weathered the storm.

The qualities which Dorab Tata brought to this work were those of tenacity rather than of originating power, and a fine financial integrity. He was always willing to pay for brains, even extravagantly if he got the best. His monument is the Institute of Science, with its encouragement of pure industrial research, and the iron and steel industry, with linked enterprises, which has created a hive of industry in the virgin forests of Chota Nagpur. The contribution of his house to the renaissance of India is the recognition of the indispensability of science to modern industry, and the patriotic vision which looked beyond ' penny-in-the-slot' enterprise to the foundation of key industries, which though expensive are essential to the economic cycle.

Stanley ReEd.

\section{Dr. B. A. Behrend}

Dr. Bernard Arthur Behrend died on March 25 this year, in Wellesley Hills, Mass., at fifty-six years of age; and a correspondent who knew him intimately has sent us the following appreciation of his life and work, to supplement the many memoirs which have appeared in our engineering contemporaries.

Behrend was a man of the widest interests, and

$$
\text { No. } 3270 \text {, VoL. 130] }
$$


made his mark and his influence felt wherever those interests drew him. As an electrical engineer his far-sighted and vigorous pioneer work made him known as in the first rank in Europe and America. His early recognition of the genius of C. E. L. Brown (Brown, Boveri and Co.), as indicated, for example, in his series of articles in 1901-2 on "The Debt of Electrical Engineering to C. E. L. Brown", illustrated his intuitive engineering faculty for seizing and advancing upon the best features of current practice, when not actually initiating them. He had been very appreciative of encouragement in his early career from such men as Gisbert Kapp and André Blondel, and this made him ever watchful to encourage and give such praise as might fairly be given to his young assistants ; indeed, many of them were of his own age or older, since he had achieved much, and had established himself, while yet quite a young man.

Behrend's literary and philosophical leanings resulted in his home being built around his library, whether in Cincinnati, Milwaukee, Pittsburgh, or Boston; while a strong antiquarian bent for early colonial furniture turned him into a collector of note. He had a wide knowledge of general scientific writings, and perhaps no man held a higher place in his esteem than Thomas Henry Huxley; he made a pilgrimage to Mrs. Huxley at 'Hodeslea' in 1910. Charles Darwin, Andrew D. White, John Perry, were intimate book acquaintances. But it was not merely such men, their fame already established, whom he held in honour, for he often showed himself an alert and aggressive champion of interests which would otherwise have continued in undeserved neglect, as witness his well-known successful activities on behalf of Oliver Heaviside.

Behrend was the recipient of many honours, and year before his death the honorary degree of doctor of engineering was conferred upon him by Darmstadt. As an American citizen he was loyal and patriotic, but believed that the time was past for intense nationalistic feeling in men of affairs. Of comparatively small stature and frail health but intense vitality, Behrend was an antagonist indeed to be reckoned with when his indignation was stirred, but was a man of large generosity, both in sentiment and practically, to a host of men who long will gratefully remember him.

As publicity has been given to the fact that $\mathrm{Dr}$. Behrend took his own life, it should be recorded here that he was convinced that he was suffering from an incurable cancer. His last years were enriched by his marriage in 1926 to Margaret Plumer Chase, of whose devotion during the long illness preceding his death he wrote in eloquent terms.

WE regret to announce the following deaths :

Prof. Bernhard Bang, formerly veterinary adviser to the Government of Denmark and professor of internal diseases at the Royal Veterinary College, Copenhagen, known for his work on tuberculosis, on June 22, aged eighty-four years.

M. Albert Durand de Grossouvre, correspondant for the Section of Mineralogy of the Academy of Sciences, Paris, aged eighty-two years.

Prof. Aimé Sneider, formerly professor of zoology in the University of Poitiers, known for his work on the parasitic Protozoa, on March 27, aged eightyseven years.

Prof. J. W. Young, professor of mathematics in Dartmouth College, Hanover, New Hampshire, author of numerous works on the fundamental concepts of algebra and geometry, on Feb. 17, aged fifty-two years.

\section{News and Views}

\section{Early Man in Java}

ON p. 20 of this issue of Nature there appears a letter on the recently found Ngandong skull, from Prof. E. Dubois, whose discovery of Pithecanthropus erectus and close association with palæontological research in Java entitle him to speak with authority on the question of early man in south-east Asia. After careful study of Dr. Oppenoorth's paper, he has arrived at the conclusion that Ngandong man and Wadjak man are one identical type. This view carries with it certain implications, to which Prof. Dubois briefly refers, of no little importance in the study of the evolution of human types. Wadjak man is represented by two skulls discovered in the terraces of a dried-up freshwater lake near the southern coast of Java, one in 1889 and the second by Prof. Dubois himself in the following year, and brought back by him from Java in 1895, but not described until 1921. These skulls have been regarded as ancestral to the Australian; but it has been pointed out, notably by Sir Arthur Keith, that Wadjak man, so far as described, presents certain points of resemblance to Rhodesian manfor example, in the relatively enormous size of the palates, of which the area is identical. Prof. Dubois regards one of the Wadjak skulls, which in this respect differ inter se, as approaching the Ngandong skull in the shape of the occiput and other points; while Oppenoorth says of the latter that it resembles the Rhodesian skull, especially in the shape of the occipital bone, while the back of the skull "bears a resemblance to the Australian race". Thus with the Talgai skull of Queensland-probably pleistocene, and probably a relative of the Wadjak man, but still more closely related to the modern Australian-the newly discovered Javan skull apparently helps to link up a group of skulls, reaching out experimentally, if not in a direct line of ascent, to the modern Australian type.

\section{Magic and Medicine Men}

AтtноUGH there is a great similarity in the supernormal performances of witches and medicine men wherever recorded, the selection of certain alleged powers of West African magicians as the subject of a challenge by the local Council of the Christian Missions (see Nature, June 11, p. 862) adds interest to the

No. 3270, VoL. 130] 